\title{
Spor o abstraktní práci: Ke konceptuálnímu založení kritiky politické ekonomie
}

\author{
The Conflict over Abstract Labour: Towards Conceptual \\ Establishment of the Critique of Political Economy
}

\author{
Martin Nový
}

\begin{abstract}
This paper highlights the recent Marxist debate on abstract labour and seeks to make Czech sociologists aware of the question. Following Marx, labour that creates commodities has a double character: as concrete labour, it is a specifically useful activity; as abstract labour, it adds value to its product. The subject of dispute is the actual content of the category of abstract labour. The interpretative problem can be found in the conflicting formula that delimits this concept in Marx's work. Marx sometimes stresses its value-creating character, while at other times he speaks of abstract labour as a productive expenditure of the human body. Rubin's solution of the riddle suggests that abstract labour is an exclusively capitalist social form of labour. Under the conditions of commodity production, exchange equalizes various kinds of concrete labour by converting them to a unit of value. From this perspective, abstract labour appears as the abstraction of labour of socially necessary labour time that is crucial for the production of value. Kicillof and Starosta criticize Rubin's approach as idealistic and argue that abstract labour represents the generic materiality of human labour, which takes the form of value in commodity production. They claim private and independent labour is the form of labour specific to capitalism. Bonefeld supports Rubin and denounces Kicillof and Starosta as falling back to the positions of political economy and affirming the capitalist conception of labour rather than criticising it ad hominem.
\end{abstract}

KEYWORDS Abstract labour, Marx, dialectics, value-form theory, Marxism, critical theory

„Řekněte laskavě své paní, že je nejvhodnější začít číst oddíly o ,pracovním dni‘, ,kooperaci, dělbě práce a strojích“ a konečně o ,původní akumulaci‘. Nesrozumitelnou terminologii jí musíte vysvětlit. Vyskytnou-li se nějaké jiné nejasnosti, jsem k dispozici."1

Sociální studia. Katedra sociologie FSS MU, 1/2014. S. 61-79. ISSN 1214-813X.

1 Tyto instrukce, které Marx (1957b: 161) poslal dopisem z 30. listopadu 1867 Ludwigu Kugelmannovi, se týkají úskalí, na něž narážela Kugelmannova manželka při pokusu o porozumění argumentaci prvních kapitol Kapitálu. 


\section{Úvod}

Proč se dnes zabývat Marxovou kritikou politické ekonomie? Především proto, že její pochopení je v sociologickém povědomí stále silně mediováno ortodoxní interpretací marxismu-leninismu. Ta zachází se způsobem, jímž Marx buduje stavbu kritického pochopení moderní společnosti, dosti staticky. Jde o učení, jež namnoze potlačuje Marxovu dialektickou metodu. V českém prostředí se ostatně volání po adekvátnější interpretaci Marxova díla objevuje již dlouhou dobu: že se dnes ,v souvislosti s marxismem objevuje [...] ignorantský úsměv", si již před časem všiml i Loewenstein (1998: 403), jehož přitom ani při nejlepší vůli mezi marxisty či jejich sympatizanty počítat nelze. Podobné podněty však zůstávaly poměrně dlouho bez odezvy. A snad i proto spatřoval Petrusek (2011) v jedné ze svých posledních publikovaných statí příslib možného rozvoje české sociologické teorie v opatrně se probouzejícím zájmu o kritickou teorii a (neo)marxismus. Pokusy o poctivé proniknutí k Marxovi však narážejí na různé překážky, jež dle autorova názoru pramení právě z nedostatečné reflexe jeho teoretické metody. Vlivným interpretem Marxe pro 21. století se stal Habermas, jenž však zanedbává jeho analýzu interní kontradikce ve společenských vztazích, pročež ,proměnil Marxe v Parsonse“, na což poukázal Holmwood (2008: 923). V Sociálních studiích nedávno Nedbálková (2012: 85) v textu, který se věnoval dělnické trrídě, usilovala mj. o ,přiblížení paradigmatických a metodologických předpokladů, které se třídou pracují jako s podstatnou a důležitou kategorií sociálněvědního výzkumu“. Marxovi zde však věnovala dvě (sic!) velmi obecné věty, aby jej takto odložila ad acta. Podle Marady (2005: 9), který klasika skutečně diskutuje, patrně představuje Marxova kritika kapitalistické totality a jejích momentů (jako je občanská společnost) projekt, který má dnes pro sociologii již jen historický význam, nebot’ ,pro jeho současné následovníky je občanská společnost [...] naopak základním východiskem a kritériem kritiky trhu a státu“. Pochopení Marxova díla, které jej chápe jako historicky překonané, však tento text nesdílí. Metodologická perspektiva jeho autora vychází v tradici kritické sociální teorie z nároku na analýzu kapitalistické společnosti jako totality a jejích prvků coby způsobů existence rozporuplně konstituovaného sociálního celku.

Ambicí této stati se nemůže stát komplexní rekonstrukce Marxovy sociologické metody. Přesto by však chtěla $\mathrm{k}$ jejímu hlubšímu pochopení svým dílem přispět: přijímá proto za svůj úkol interpretaci kategorie abstraktní práce. Ke zmírnění zřejmého deficitu, jímž je v českém prostředí (ne)diskuze myšlenkového podloží, z něhož vyrůstá marxistická teorie, přispěje obrácením své pozornosti na nedávný spor o abstraktní práci. Tato debata se odehrála zejména na stránkách marxistických časopisů Historical Materialism a Capital \& Class. Porozumění zde vysloveným argumentům však předpokládá jednak elementární obeznámenost s Marxovým pojmem abstraktní práce a jednak povědomí o Rubinově interpretaci této kategorie, okolo níž se celý spor rozhořel. Kromě interpretace polemiky a jejího předmětu se stat' též v jisté - byt' dosti omezené - míře dotýká konceptuálních základů, na nichž vrcholné Marxovo dílo stojí. Může tak činit proto, že expozice abstraktní práce je v Marxově tvorbě úzce provázána s pochopením kapitalistické totality. Abstraktní práce je kategorií, s níž se lze v sociologických výkladech Marxova díla setkat jen výjimečně, a to i přesto, že jde o silný sloup, jenž podpírá Marxovo pochopení stavby moderní společnosti. 


\section{Marxưv pojem abstrakłní práce}

Marx rozvíjí komplexní koncept abstraktní práce především v prvních kapitolách Kapitálu, ještě dř́ve ve své průkopnické práci Ke kritice politické ekonomie. Rekonstrukce této kategorie v klasikově díle proto vychází zejména ze zmíněných klíčových textů. Podle Marxe se společenská dělba práce v kapitalistickém výrobním způsobu zakládá na produkci zboží. Ve snaze odhalit určité abstrakce, skrze něž se ustavuje sociální realita, přikládá Marx (1974: 19) analýze společenské determinace zbožní výrobou klíčový význam; v jeho analýze jde o jednotlivce ,jen potud, pokud jsou personifikací ekonomických kategorií, nositeli určitých třídních vztahů a zájmů“. Mluví-li Marx (ibid.: 98) o dělníkovi či kapitalistovi, pojednává je coby „charakterové ekonomické masky osob“, jež ,jsou jen personifikací ekonomických vztahů, jejichž nositelé jako tyto osoby vičci sobě vystupuji“". Marx tedy v těchto pasážích svého díla neusiluje o odhalení sociálních proměnných, jež ovlivňují individuální jednání, ale o uchopení podkladu, na němž se odehrává ustavování sociální reality. Analyzuje podmínky existence a rozpory kapitalistické sociální praxe. V těch společnostech, kde lidé vyrábějí př́mo pro svou spotřebu, je výroba zboží pro směnu na trhu spíše okrajovým jevem; tyto společnosti charakterizují jiné určité abstrakce; jde o jinou společenskou souvislost. Nicméně již zde tyto kategorie vznikají a historicky se vyvíjejí, aby se v kapitalistickém výrobním způsobu staly prvními předpoklady sociální konstituce. „Kategorie“ kapitalistické společnosti, „které vyjadřují její vztahy, pochopení její struktury, dovolují proto zároveň proniknout do struktury výrobních vztahů všech zaniklých forem společnosti. Anatomie člověka je klíč k anatomii opice,“ ujasňuje si Marx (1971: 59) implikace dějinně specifické podmíněnosti projektu kritického pochopení sociální reality v Rukopisech Grundrisse.

$* * *$

„Zboží je především vnější předmět, věc, která svými vlastnostmi uspokojuje nějaké lidské potřeby“ (Marx 1978: 51). Aby se tak dělo, musí být zboží užitečné, přinášet svému spotřebiteli užitnou hodnotu. V kapitalistické společnosti se však užitná hodnota snoubí s hodnotou směnnou. Ta odkazuje ke směnitelnosti zboží, k té jeho vlastnosti, že se zboží různých druhů na trhu směňují v jistých kvantitativních poměrech, jež se „neustále mění podle doby a místa“ (ibid.: 52). Zboží tedy představuje jednotu užitné hodnoty a směnné hodnoty. Nahlížíme-li zboží z kvalitativní stránky, všímáme si jeho užitné hodnoty; zkoumáme-li však zboží z hlediska kvantitativního, $\mathrm{z}$ hlediska jeho směnných poměrů $\mathrm{k}$ jinému zboží, dostáváme se $\mathrm{k}$ jeho směnné hodnotě. Zatímco se v užitné hodnotě věci zračí konkrétní práce, nějaká specificky vynaložená práce (např. truhláře nebo učitele), ve směnné hodnotě se obráží pouze skutečnost, že je zboží zároveň produktem lidské práce obecně, práce bez jejího specifického užitečného určení, abstraktní lidské práce. Lidskou práci proto v kapitalismu charakterizuje její dvojaká povaha: jako konkrétní práce vytváří užitnou hodnotu, jako abstraktní práce hodnotu směnnou. „Abstrahujeme-li skutečně od užitné hodnoty produktů práce, dostaneme jejich hodnotu, jak byla právě určena. To společné, co je vyjádřeno ve směnném poměru čili ve směnné hodnotě jednotlivých zboží, je tedy jejich hodnota“ (ibid.: 54). Velikost hodnoty pak lze měřit společensky nutnou pracovni dobou, tedy průměrnou pracovní dobou, za kterou dělník při vynaložení pracovní síly „společensky obvyklým stupněm intenzity“ (ibid.: 202) vyrobí dané 
zboží. Z tohoto důvodu nepřidává práce jednotlivého dělníka hodnotu výrobku sama o sobě, prímo, ve své individualitě, ale skrze mediaci společensky nutnou pracovní dobou. Dělník může za svůj pracovní den vyrobit větší či menší množství hodnoty, což se ale neprojeví na ceně jednotlivého zboží, jež vyrobil, nebot' ta se na trhu odvíjí právě od abstrakce společensky nutné pracovní doby, která se ustavuje nikoli v individuálním, nýbrž v celkovém produkčním procesu. Společensky nutná pracovní doba je proměnlivá: závisí na technologické rozvinutosti výrobního procesu, nebot' ta ovlivňuje produktivní sílu práce; na aktuálním stavu tř́íního boje (čili na tom, jak mnoho jsou dělníci vykořistováni) i na kulturních zvyklostech čili na „tradičním způsobu života“ dané společnosti (Marx 1949: 74).

Zanedbávání dvojakého charakteru kapitalistické práce je typické pro politickou ekonomii, již Marx podrobuje kritice. ${ }^{2}$ Politická ekonomie přistupuje ke svému předmětu ahistoricky; s dějinně vzniklou kapitalistickou ekonomikou zachází jako s př́rodní skutečností, a proto se nevědomky stává podpěrou stávajícího společenského zřízení. Namísto toho, aby kriticky pronikla sociální souvislost, a tak i konceptuální zdroj svých kategorií, aby si položila „otázku, proč tento obsah přijímá takovou formu, proč se práce zračí v hodnotě“, ulpívá na existujících ekonomických jevech jako na bezrozporně dané a konstituované skutečnosti (Marx 1978: 94). Ricardo (ibid.), Franklin (Marx 1955b: 38-39) i Smith (Marx 1955a: 394-395) chápou práci, která vytváří hodnotu, čistě kvantitativně, technicistně, pročež ulpívají na jevových formách sociální reality a tak či onak podléhají iluzi zbožního fetišismu. Klasická politická ekonomie nechápe konceptuálně určitý charakter kapitalistické práce, který se - na rozdíl od jiných historických podob práce - projevuje ve formě všeobecné směnitelnosti jejího produktu. Protože politická ekonomie naturalizuje ekonomické kategorie, uzavírá si přístup k rozkrytí určujících sociálních souvislostí, jimiž jsou tyto kategorie podmíněny. Marxova kritika fetišového jevení se hodnotové formy však není pouze př́spěvkem do debat dobových ekonomů, ale je především sociologickou kritikou a proniknutím zdroje sociální konstituce kapitalistické konceptuality. Kapitalistický výrobní způsob, tyto historicky určité společenské vztahy, pak ve svých jevových formách produkují falešné sebe-vědomí, které odpovídá jejich konceptuální esenci. Nebot' kapitalistická společenská práce existuje jako soukromá práce jednotlivých výrobců, nejsou tito s to nahlédnout sociální pre-strukturovanost své individuální činnosti. „Výrobcům se proto společenské vztahy jejich soukromých prací jeví jako to, co jsou, tj. ne jako bezprostředně společenské vztahy mezi osobami v jejich pracích, nýbrž naopak jako věcné vztahy osob a společenské vztahy věcí“ (Marx 1978: 87).

Kapitalistickou abstraktní práci tedy v prvé řadě charakterizuje její kvalitativní bezrozdílnost; skutečnost, že se každá konkrétní práce, která produkuje zboží - nabývá tedy zbožní formy -, musí prokázat jako práce abstraktní. Abstraktní práce je ve společnostech, jejichž výrobní způsob je založený na produkci zboží, modem vivendi práce konkrétní. Tato její bezrozdílnost vyrůstá z existence zboží qua hodnoty, jež se projevuje ve směnné hodnotě zboží.

2 „Pokud však jde o hodnotu vůbec, nerozlišuje klasická politická ekonomie nikde výslovně a naprosto vědomě mezi prací, která se zračí v hodnotě, a touž prací, pokud se zračí v užitné hodnotě svého výrobku [...] nenapadá ji, že pouze kvantitativní rozdílnost prací předpokládá jejich kvalitativní jednotu, čili rovnost, tedy jejich redukci na abstraktně lidskou práci“" (Marx 1978: 94). 
Rozličné práce samy musí být převedeny na bezrozdílnou, stejnorodou, jednoduchou práci, zkrátka na práci, která je kvalitativně táž [...] Toto převedení se jeví jako abstrakce, ale je to abstrakce, která se denně provádí ve společenském výrobním procesu [...] Čili práce tak, jak se zračí ve směnných hodnotách, mohla by být vyjádřena jakožto všeobecně lidská práce. Tato abstrakce všeobecně lidské práce existuje v průměrné práci, kterou může vykonat každé průměrné individuum dané společnosti; je to určité produktivní vynaložení lidských svalů, nervů, mozku atd. (Marx 1955b: 14)

Tato i jiné Marxovy (1978: 86, 87) formulace zakládají interpretaci abstraktní práce, která ji chápe jako prostou, historicky invariantní fyziologickou či materiální skutečnost, jako jednoduchý účelný výdaj lidské energie, jehož kapitalistické specifikum tkví v tom, že nabývá hodnotové formy.

Na jiných místech ovšem Marx mluví o sociální povaze abstraktní práce: ,práce tvořící směnnou hodnotu je specificky společenskou formou práce“ (Marx 1955b: 20). Protože „hodnotovost zboží je čistě společenská“ - sociální vztahy, v nichž se uspokojování lidských potřeb realizuje skrze produkci pro tržní směnu, jistě nejsou sine qua non lidské existence -, jsme s to abstraktní práci, se zřetelem na nerozlučitelnou jednotu užitné a hodnotové stránky zboží, analyticky odlišit od práce konkrétní (Marx 1978: 63). Abstraktní práce je sociálně zvláštním momentem v procesu zbožní výroby, jelikož ve své kvalitativní bezrozdílnosti, na niž redukuje rozličné konkrétní práce, vytváří hodnotu. Reálně se ale abstraktní práce sociálně validuje až ve směně na trhu. Jen zde se „mưže fakticky ukázat, zda je práce užitečná pro jiné, zda tedy její produkt uspokojuje nějakou cizí potřebu“ (ibid.: 99). Řečeno prozaicky: směnná hodnota zboží se realizuje až tehdy, když je vyrobené zboží prodáno. Tak zároveň nabývá specifická práce soukromého výrobce společenský obsah: „,práce soukromého jedince musí, aby měla společenský význam, se zračit jako její bezprostřední opak, jako abstraktně všeobecná práce“ (Marx 1955b: 50). Hodnota, jež je pro Marxe (1978: 54) nepochybně dějinně určitým společenským vztahem, se proto projevuje ve formě směnné hodnoty; směnná hodnota je „nutnou jevovou formou“ hodnoty. Napětí mezi fyziologickým či materiálním pochopením abstraktní práce a její interpretací jako historicky přechodné kategorie kapitalistické sociální reality se ocitá v jádru polemik, jež se o abstraktní práci v nedávné době svedly. At’ již dáme přednost „,sociálnímu“ či „materiálnímu“ čtení tohoto konceptu, odkazuje abstraktní práce k základnímu zdroji dynamiky moderní společnosti, jenž se ukrývá v pojmu kapitálu čili existence hodnoty v pohybu sociální reality. Souvislost hodnoty a abstraktní práce explikuje a pojmově proniká zásadní odlišnost charakteru práce v moderní společnosti, jíž člověk vytváří sebe sama. Jak přesně uchopit vztah hodnoty a abstraktní práce a jak jejich vztah souvisí s kritickou teorií kapitalismu? Bitevním polem, na němž probíhají střety mezi současnými marxisty, se stalo zhodnocení Rubinova př́spěvku k tématu.

\section{Rubinova rekonstrukce abstraktní práce}

Rubin $(1978,1990)$ obohatil interpretaci abstraktní práce zejména v knize Eseje o Marxově teorii hodnoty a ve svých moskevských přednáškách z května a června 1927, které byly 
následně publikovány. ${ }^{3}$ Rubin si všímá Marxových metodologických postupů, aby je později usouvztažnil s expozicí konceptu abstraktní práce $\mathrm{v}$ jeho díle. Rubin u Marxe rozlišuje dvojí prístup: jednak analytickou metodu, kterou charakterizuje abstrakce od komplexity jevu s cílem proniknout $\mathrm{k}$ jeho esenci, a jednak metodu genetickou či dialektickou, jež v jisté abstrakci zasazuje studovaný jev do procesu geneze a logiky imanentního vývoje komplexních společenských forem. Pouze dialektická metoda je však vědecky uspokojivá, pouze ona dovoluje adekvátně zahrnout do pochopení sociálních fenoménů jejich historickou situovanost. ${ }^{4}$ Rozdíl mezi fyziologickým a sociologickým pochopením abstraktní práce pak odpovídá rozdílu mezi těmito metodami: zatímco použitím analytické metody lze odhalit fyziologický pojem abstraktní práce, dialektická metoda dává vyniknout historicko-sociální specifičnosti zbožní výroby, aby v abstraktní práci zobrazila sociální podmíněnost kapitalistického zpředmětňování lidské práce ve formě hodnoty. Založíme-li analýzu zboží ahistoricky, jen jako jeho anatomii, dostaneme pouze fyziologický koncept abstraktní práce. Uvažujeme-li však o zbožní výrobě též jako o určitém, historicky přechodném společenském vztahu, pak získává abstraktní práce stěžejní sociologický obsah.

Podle Rubina tedy musí pochopení Marxova systému začít od sociálního ustavování lidské práce, a nikoli a priori vycházet z kategorie hodnoty či z jakéhokoli jiného pojmu. Marxovi jde o pochopení sociální organizace práce, v níž práce nabývá formu hodnoty coby základní sociální formy. Koncept abstraktní práce pak umožňuje plynule přejít od konkrétní práce $\mathrm{k}$ celku společenské dělby práce, pro nějž má hodnotová forma určující význam. Rubin (1990: 139) proto uvažuje o třech koncepcích rovné práce u Marxe. První z nich je „fyziologicky rovná práce“, vynaložení fyzické či duševní energie lidského těla, kterážto rovnost má transhistorický charakter. Druhou je „sociálně rovná práce“, která odkazuje k různým historickým podobám společenské dělby práce, avšak činí tak bez toho, aby se jimi zabývala v jejich jednotlivostech. Třetí je „abstraktní či abstraktně univerzální práce“, která je rovnou prací v historicky určitých společenských vztazích, v kapitalistickém výrobním způsobu, kde se práce objektivizuje ve formě hodnoty. V podmínkách zbožní výroby se toto narovnání rozličných konkrétních prací odehrává skrze směnu produktů práce na trhu. Směna tak reguluje výrobu zboží dle konceptuálního určení a potřeb akumulace kapitálu. Abstraktní práce je proto rovnou prací, avšak tato rovnost patř́ k sociálním vztahům, ve kterých produkty práce získávají zbožní formu, kde se tedy vyrábí pro trh, a ne pro př́mé uspokojování lidských potřeb, pro př́mou spotřebu. Abstraktní práce předpokládá fyziologickou a sociální rovnost

3 Tím si však věru neposloužil, nebot' se výsledky jeho kritického a nekonvenčního př́stupu ke zkoumání Marxova díla nekryly s oficiální linií Sovětského svazu. Roku 1930 byl poprvé zatčen, odsouzen a veřejně denuncován, aby byl po třech letech strávených na samotce poslán do vyhnanství na území dnešního Kazachstánu. Zde se snažil dále vědecky pracovat, avšak roku 1937 byl zatčen znovu a jeho stopa zde končí (Rubin 1978: 108).

4 Marxův požadavek na interpretaci nálezů učiněných za použití analytické metody jejich začleněním do klenby historického vývoje, který je schopna adekvátně pochopit pouze metoda dialektická, lze ilustrovat již na Ekonomicko-filosofických rukopisech z roku 1844, kde se Marx (1961: 143) emfaticky vyjadřuje, že ,dějiny jsou opravdovým prŕrodopisem (Naturgeschichte) člověka“. 
práce, ale oproti nim je v ní navíc ukryta i specifická forma, forma hodnoty, která se váže ke zbožní výrobě.

Proč však Marx exponuje abstraktní práci způsobem, který může zakládat její pochopení jako fyziologické práce? Rubin nachází odpověd’ v hegelovské struktuře Marxova argumentu, jenž ukazuje rozpor ne coby tenzi mezi různými kauzálními vlivy, ale jako imanentní prvek sociální reality. Marx ve své koncepci fetišového charakteru zbožní výroby odhaluje ontologickou inverzi, kdy se smyslově konkrétní překlápí v určitou abstrakci. Zboží, produkt konkrétní lidské práce, tak nabývá formu abstraktní univerzality. Tím, co převádí konkrétní práci na abstraktní ekvivalent, je směna; ne však jako jednorázový akt, ale jako nutný konceptuální doplněk výrobního procesu. Směna tak dotváří koncept kapitálu, ,hodnoty, která se sama zhodnocuje“, či, řečeno snad lépe, je jeho interní součástí (Marx 1978: 201). V procesu kapitalistické reprodukce pak směna hraje roli realizace produktů práce coby práce odcizené. Rubin (1990: 145) proto pozoruje u výrobců nezájem o jejich konkrétní práce; směna se tak sama stává určitou formou výrobního procesu. Směna vtiská soukromé aktivitě výrobců jasnou sociální pečet; funguje jako test sociální validace individuální ekonomické aktivity. Hodnota proto není transcendentní univerzálií, obecně platnou formou zpředmětňování lidské práce, ale takovou její objektivizací, která si osvojila formu směnitelnosti výrobku práce. Takto rozvíjí Marx plynulý přechod mezi prací, která $\mathrm{v}$ určitých společenských vztazích vytváŕí hodnotu, a směnnou hodnotou, jež je projevem hodnotovosti zboží ve směně. Jelikož hodnotovou formu práce nelze pochopit z žádného druhu konkrétní práce, rekonstruuje Rubin abstraktni práci jako kategorii, která u Marxe zaplňuje pojmovou prohlubeň mezi pracís coby antropologickou konstantou člověka a hodnotou jako dějinně výlučným sociálním vztahem. Abstraktní práce je z tohoto titulu specificky kapitalistickou formou práce.

\section{Znovuobjevení Rubinova pojetí abstraktní práce $v$ 70. letech a jeho další rozvíjení}

K Rubinově koncepci abstraktní práce se váže nárok na integrované pochopení Marxova díla, které proti sobě strnule nestaví „mladého Marxe“ s pojmem „odcizení“ na jedné straně a „zralého Marxe“ s kategorií „hodnoty“ na druhé. Snaží se proniknout do imanentní logiky jeho vývoje, kterážto cesta vede k zájmu o rozvíjení analytických kategorií, s jejichž pomocí Marx rozkrývá dějinně specifické předpoklady existence kapitalistické sociální reality. Tento projekt nakonec ústí v reflektované porozumění dialektické expozici kategorií v Kapitálu, jež umožňuje artikulaci jejich genetické interpretace. ${ }^{6} \mathrm{~K}$ oživení této „rubinovské“ perspektivy zkoumání Marxova díla dochází zejména od 70. let 20. století ve Velké Británii a v západním

5 „Práce je především proces, probíhající mezi člověkem a př́rodou, proces, v němž člověk svou vlastní činností zprostředkovává, reguluje a kontroluje výměnu látek mezi sebou a př́rodou. Člověk [...] uvádí do pohybu přírodní síly, které patří k jeho tělu, paže i nohy, hlavu i ruce. Tím, že tímto pohybem pưsobí na vnějši prírodu a měni ji, mění zároveň svou vlastní přirozenost" (Marx 1978: 184; zvýraznění MN).

6 Pokud bychom chtěli uvést př́klad, odkážeme čtenáře na kontrast jemného pojmového aparátu Kapitálu a např. jisté hrubosti, s níž se Marx (1975: passim) vyjadřuje o „,̌achru“ v polemice 
Německu. Zajímavé je, že se tak děje poměrně nezávisle na sobě, v kontextech rozvíjení různých myšlenkových tradic. Ve Spojeném království se začíná rozvíjet marxistická teorie hodnotové formy (Arthur 2001, 2006) a souběžně s ní se v Konferenci socialistických ekonomů (CSE) vedou polemiky s ortodoxní interpretací kategorií Kapitálu, která vychází z Druhé internacionály, a s marxistickým strukturalismem (Clarke 1991). Diskutuje se dědictví sociálních bojů v 60. letech, reprezentované autonomistickými proudy marxismu orientovanými na aktivní sebe-ustavování proletariátu v třídním boji. Ve Spolkové republice Německo se dialektikou hodnotové formy a rekonstrukcí Marxovy teoretické metody zabývají autoři vycházející z velmi hlubokých znalostí nejen Marxova díla, ale patrně i všech jeho myšlenkových zdrojů. V mnoha ohledech tak navazují na interpretaci Marxe v kritické sociální teorii Frankfurtské školy, kterou však díky svému užšímu fokusu na mnoha místech překračují. Badatelské úsilí Adornových žáků Backhause (1980, 1992, 2005, 2011) a Reichelta (1995, 2000, 2005, 2007) se dnes považuje za založení školy nového čtení Marxe (Neue-Marx Lektüre). ${ }^{7}$

Skutečnost, že se právě zmíněný „,britský“ i „,německý“ proud výrazněji projevují jako ,heretické př́ístupy v marxismu právě od 70. let 20. století, však není náhodná: začátkem 70. let dochází v důsledku evoluce poválečného modelu akumulace kapitálu k ekonomickým potížím, které jsou ještě umocněny ropným šokem. Krizový socio-ekonomický vývoj vede $\mathrm{k}$ postupnému rozkladu keynesiánského managementu kapitalistických sociálních vztahů a $\mathrm{k}$ rozpadu brettonwoodského systému měnových vztahů mezi vyspělými státy, v němž nacházelo keynesiánství oporu pro deficitní financování poptávky (Kliman 2012). Prolegomenu k ekonomické krizi představoval na Západě rok 1968, který vrhl stín pochybností na ortodoxní marxistickou interpretaci metody historického materialismu. V průběhu ekonomické krize se stávají abstraktní zákony, rozpory a antagonismy vývoje kapitalistických sociálních vztahů mnohem viditelnějšími; ,kontradikce $v$ esenci“ a iracionalita zhodnocující se hodnoty se od konce 70. let v nástupu monetarismu a neoliberalismu manifestují zcela otevřeně (Arthur 2006). Ekonomická krize je tak zároveň krizí sociální; je krizí hodnoty, již Marx, jak již víme, teoretizuje jako společenskou realitu sui generis.

Nás zde však zajímají teoretické plody, jež reflexe vnitřní kapitalistické negativity vydala: k prolnutí „,britské“ a „německé“ diskuze přispívá roku 1977 založení časopisu CSE Capital \& Class, aktivita Picciotta a Hollowaye (1978), kteří přibližují anglosaskému světu německou debatu o odvozování povahy kapitalistického státu (Staatsableitungsdebatte), i úsilí Bonefelda, Gunna a Psychopedise (1992a, 1992b; Bonefeld et al. 1995). Ti ve třech svazcích Otevřeného marxismu (Open Marxism) plédují za pochopení marxistických kategorií jako otevřených nástrojů interpretace sociální reality, jejichž obsah je třeba vždy vztahovat ke konkrétnímu momentu vývoje, k historicky určité konfiguraci kapitalistických společenských vztahů. V poslední době se v tomto poli odehrává diskuze o významu Adornovy kritické teorie kapitalismu (viz Holloway, Matamoros, Tischler 2009; Bonefeld 2012).

s Brunem Bauerem $K$ židovské otázce. Marx však má v obou př́ípadech na mysli panství týchž kapitalistických abstrakcí.

7 Vzhledem k charakteru těchto prací, jež detailně analyzují zdroje, vývoj i interpretaci Marxových kategorií, jsou texty Neue Marx-Lektüre napůl vážně, napůl žertem označovány jako „marxistická filologie". 
V čem se tedy odrazil význam Rubinova výkladu abstraktní práce? Arthur si všímá, že se u Marxe abstraktní práce diskutuje jako koncept patřící ke směně zboží. Důvodem tohoto pojetí je, že průmyslový kapitál přistupuje ke všem konkrétním pracím stejně, nebot' je uvažuje z hlediska možnosti jejich vykořistění. Arthur tak rozvíjí motiv, který s abstraktní prací spojuje Rubin: je jím ontologická inverze subjektu v objekt; sociální proces, v němž si lidská práce osvojuje kapitalistickou formu. Kapitál totiž nemůže vykořistit jakoukoli konkrétní práci, ale pouze „konkrétně univerzální“ práci, která bude ve svém konkrétním obsahu a průběhu strukturována abstraktní potřebou akumulace kapitálu (Arthur 2001: 20). Možná ještě explicitněji se abstraktní společenská určenost konkrétní práce obráží v situaci, kdy je člověk nezaměstnaný a práci si hledá: ke konkrétnímu obsahu své pracovní činnosti přistupuje s notnou dávkou indiference, zajímá jej, aby vůbec nějakou práci, za kterou bude dostávat mzdu, získal. Jeho vztah ke konkrétní práci zde rovněž mediuje její abstraktní, odcizená kapitalistická konceptualita. Arthur však zároveň varuje před chápáním konkrétní fyzické či mentální aktivity v produkčním procesu přímo jako abstraktní práce: abstraktní práce je konceptuální „determinací sociální formy“, která specifické pracovní činnosti „abstraktně totalizuje“ (ibid.: 21). Abstraktní práce tedy ve směně uděluje práci hodnotovou formu. „Ve skutečnosti je abstraktní práce jako determinace formy živé práce námezdního dělníka a abstraktní práce coby práce objektivizovaná ve zboží touž věcí, která v jednom případě vypadá jako aktivita, v jiném jako její výsledek“" (ibid.: 24).

Zatímco Arthur vychází z Rubina programově a př́mo se na jeho dílo odvolává, Němci se dostávají do blízkosti jeho myšlenek díky diskuzi implikací Adornovy metodologické kritiky. Ve slavném Sporu o pozitivismus v sociálních védách (Positivismusstreit, který je znám též jako třetí německá debata o metodě) Adorno (1993) opakovaně mluví o konceptualitě věci samé, o abstrakci, která se ukrývá ve společenských fenoménech. Koncepty, které sociologie používá, se proto mají snažit tyto určité abstrakce rozkrýt a kriticky je zhodnotit ad hominem. Úkolem sociologie je proto spíše obnažení konkrétního způsobu existence sociální esence, jež mediuje veškeré společenské dění, než ad hoc testování konceptů ve formě hypotéz, které sociolog na sociální realitu, začasto externě a neorganicky, přikládá. $Z$ důvodů, jejichž explikace značně přesahuje rozsah této stati a které její autor diskutuje jinde (Nový 2014), považuje Adorno (1993: 94) za společenskou podstatu směnu. Abstraktní ekvivalent se ve směně stává pojítkem, jež k sobě virtuálně váže všechny ty, již na směnném procesu participují. Uvaluje na ně jistou svou abstraktní identitu, vytváŕí první podmínku jejich existence, které si účastníci směny zboží nejsou vědomi.

Ve směně se nejen realizuje hodnota zboží, ale vychází zde na povrch též určitá forma inverze subjektu v objekt. Směna různých druhů zboží subsumuje tyto rozličné produkty lidské práce pod jistou historicky zvláštní a sociálně univerzální kvalitu. Takto se na nejobecnější rovině v subjektivitě lidského jednání reprodukuje a modifikuje společenská objektivita. Na kategorie subjektu a objektu se však v sociologii nesmí pohlížet prismatem tradiční binární opozice; postavíme-li vědu o společnosti na přírodovědné koncepci objektivity, ignorujeme specifický charakter jejího předmětu, jehož výlučnost tkví v tom,

$8 \quad$ Prodej a nákup pracovní síly na trhu práce jsou též akty směny. 
že - na rozdíl od př́rodních jevi̊ - ustavuje sebe sama. Narýsování externího vztahu mezi subjektem a objektem nám proto neumožňuje spatřit „,kvalitativní rozdíl mezi fyzikou a společenskými vědami“" (Backhaus 1992: 66). V kapitalistických sociálních vztazích probíhá způsob, jímž subjekt rekonstituuje objekt, slepě, nevědomě. Kapitalistická sociální produkce je podmíněna výrobou zboží a zbožní fetišismus předvádí „společenský vztah mezi lidmi samými“ jako prírodní vztah mezi věcmi, přičemž „fetišismus světa zboží vyplývá [...] ze zvláštního společenského charakteru práce, která vyrábí zboži““ (Marx 1978: 87). Sociální objektivita tak existuje díky mystifikované sebe-produkci subjektu, jejímž nutným výsledkem je falešná společnost. Vědecký projekt, který se snaží konkrétní podobu sociální reality popsat tout court, který neusiluje o její hlubší reflexi, je proto odsouzen ke kladení fetiše za horizont své ,analýzy“, namísto aby fetiš kriticky pochopil, což zahrnuje porozumění společenskému zdroji, který jej konstituuje. Sklouznutí po jevové formě, po povrchu sociálního fenoménu, vychází rovněž z neschopnosti „,adekvátně rozlišovat mezi dvěma významy ,objektivní‘, a tak směšuje ,objektivní ve smyslu mimo-mentální s ,objektivní ve smyslu mimo-lidský, totiž objektivity vně lidskou doménu“ (Backhaus 1992: 67).

Podle Reicheltovy (2005) rekonstrukce abstraktní práce se u Marxe odehrává ustavování sociálních forem skrze hodnotu; mediaci hodnotou jeho argument předpokládá kvůli výše diskutovanému určitému charakteru kapitalistických abstrakcí. Všichni ti, kdo participují na směnném procesu, ustavují sociální formu; různé konkrétní práce se ve směně ustavují tak, jako by se jednalo o kvalitativně stejné práce. Pochopení redukce konkrétní práce na abstraktní práci $\mathrm{v}$ tržní směně pak vychází $\mathrm{z}$ hodnotové formy. Tu získávají rozličné druhy konkrétní práce již ve výrobním procesu (nebot' v kapitalismu je produkční proces zároveň hodnototvorným procesem), ale jako reálná společenská forma se hodnotová forma stává platnou až ve směně. Bezprostřední forma směnitelnosti pak představuje „bezprostřední jednotu validity a bytí“ (ibid.: 57). Univerzalita abstraktní práce se ve směně validuje jako existující univerzalita konkrétní práce. Směňovaná (tj. realizovaná) partikulární práce je tak obsažena $\mathrm{v}$ abstraktně obecném, a je proto součástí totality reálných abstrakcí (Realabstraktion); je tak něčím objektivně konceptuálním. „Centrální osa buržoazní společnosti se stvrzuje pouze ve formě univerzálního, bezprostřední směnitelnosti. Tato forma je [...] formou sebe-vědomí - vědomí svázaného s objekty, vlastním objektivizovaným já vědomí“ (ibid.: 58). Objektivizace práce, o níž je řeč, představuje skutečnost, jež ekonomii vymezuje její výzkumné pole (Backhaus 1992, 2005). Tato věda však k objektu svého zkoumání přistupuje bez toho, aby svůj předmět pochopila jako kontradiktorně konstituovanou a konstituující se formu určité abstrakce. Redukce konkrétní práce na abstraktní práci je pro naprostou většinu ekonomů př́rodní skutečností. I kvůli tomu je pro ekonomii metodologie Marxova díla neproniknutelnou záhadou: „pro Marxe byla teorie hodnoty od začátku teorí ekonomického objektu, a vůbec ne teorií směny coby teorie směnné aktivity" (Backhaus 2005: 26). Adekvátní rekonstrukce Marxových kategorií představuje pro ekonomii mysterium tremendum zejména proto, že jeho uvažování vyrůstá z antropologického substrátu. Je kritikou jisté sociální reality, kterou člověk vytváří a která se mu jeví a podrobuje si jej jako na něm nezávislá, domněle prírodní síla (ibid.: 28). 


\section{Kicillofova a Starostova kritika Rubinova cirkulacionismu}

Rubinovy úvahy o postavení a významu abstraktní práce v Marxově díle nacházejí ohlas u menšiny marxistů, kteří se těmito problémy zabývají; nicméně lze říci, že v období od 70 . let až dosud šlo o menšinu průběžně sílící. Kicillof a Starosta (2007a: 11) však hledí na tento vývoj v interpretaci kritiky politické ekonomie se značným despektem. Jejich zásadní výtkou vůči Rubinovi a jeho pokračovatelům je „problematická koncepce umístění materiálních determinací lidského života v kritice politické ekonomie“. Proto ve svých př́spěvcích k otázce porozumění abstraktní práci explicitně namířili svůj kritický osten právě proti Rubinovi. Podle nich Rubin zanedbává materiální charakter výrobních sil ve prospěch jednostranné konceptuální analýzy výrobních vztahů. $\mathrm{V}$ důsledku toho pak není s to brát přiměřeně v úvahu kvalitativní stránky rozvoje výrobních sil; jediné, co z výrobních sil v jeho analýze zůstává, je jejich kvantitativní růst, čímž nápadně připomíná marx-leninskou ortodoxii. Ve své př́lišné orientaci na směnný proces, kterou Kicillof a Starosta nazývají „,cirkulacionismus“, jako na neoddělitelný prvek kapitalistické ekonomiky Rubin nedokáže adekvátně zohlednit materiální determinace bezprostředního výrobního procesu. V momentu směny je podle nich abstraktní práce již uskutečněná, nebot' je zhmotněná ve výrobku. S pochybeným předsunutím významu oběhu zboží před jeho produkci pak přímo souvisí Rubinovo čtení abstraktní práce. Proti němu Kicillof se Starostou argumentují, že forma všeobecné směnitelnosti je vlastní samotnému produktu práce, který nabývá formy hodnoty.

Podle Kicillofa a Starosty není pravdou, že se lidská práce stává abstraktní pouze ve společnosti, která vyrábí zboží. S odkazem ke shora uvedeným Marxovým „fyziologickým“ formulacím Kicillof a Starosta tvrdí, že abstraktní práce je „výdej lidského těla, živých lidských energií“ (ibid.: 20). A právě takto všeobecně materiálně vymezená práce se v kapitalismu, bez ohledu na svůj konkrétní charakter, reprezentuje v hodnotové formě. Kategorií abstraktní práce proto nelze uspokojivě vysvětlit specifickou společenskou povahu zbožní výroby. Abstraktní práce umožňuje Marxovi v Kapitálu uchopit „všeobecnou materialitu“ (ibid.: 22) lidské pracovní činnosti, která si v kapitalistickém výrobním způsobu osvojuje sociální formu hodnoty. Abstraktní práce jistě je „hodnototvornou substancí“, avšak je jí ve svém materiálním, a nikoli společenském rozměru (Marx 1978: 55). Zbožní formu tak konstituují jak materiální, tak i sociální determinace; je ji třeba nahlížet jako jejich imanentní jednotu. Rubin však tuto vrstvu Marxova argumentu zcela přehlíží, aby tak zapudil materialistické založení jeho analýzy. Jeho umělé oddělování materiálních a sociálních determinací práce, jež vytváří hodnotu, jej dovádí k idealistickému pochopení kritiky politické ekonomie. Namísto hodnoty, která je výhradně kapitalistickou sociální formou a „,v níž se reprezentuje část vynaložení lidské tělesné existence“, tedy materiality abstraktní práce, dosazuje Rubin abstraktní práci samu; ulpívá proto na jevových formách sociální reality (Kicillof a Starosta 2007a: 32). V centru jeho pozornosti nestojí sociální esence (hodnota), nýbrž její jevová forma (směnná hodnota). Protože ve svém pojmu abstraktní práce nezohledňuje tenzi mezi materiálním substrátem bezrozdílné lidské práce a sociální výlučností hodnotové formy, není schopen pochopit pohyb rozporu v kapitalistické realitě. ${ }^{9}$

9 Kicillofova a Starostova kritika Rubinovy koncepce abstraktní práce není jejich jediným př́spěvkem k interpretaci základních konceptů kritiky politické ekonomie. Polemizují též s představitelem 
V čem však podle Kicillofa a Starosty (2007a: 28) spočívá historické specifikum kapitalistické práce, nejde-li o práci abstraktní? Je jím „soukromá a nezávislá forma, skrze kterou se organizuje sociální charakter bezprostředního procesu výroby užitné hodnoty (a odtud lidského života)“. V tomto procesu pak směna funguje jako jeho mediace; jako „konkrétní forma oběhu společenského bohatství“. Soukromá a nezávislá práce výrobců se tak stává esenciálním sociálním určením práce zhmotněné ve zboží. Charakterizuje ji na jednu stranu plné vědomí a ovládnutí individuální práce, na druhou však nevědomí sociální povahy práce, a proto i neschopnost práci organizovat a uspokojovat lidské potřeby (Starosta 2008: 308309). Rubin převrací tuto stěžejní determinaci naruby; „odnímá bezprostřednímu výrobnímu procesu jeho vnitřní sociální determinaci, aby ji nahradil sférou směny“ (Kicillof a Starosta 2007a: 30). Klíčem pro pochopení Marxových analýz kapitalismu proto podle Kicillofa a Starosty není abstraktní práce, ale nezávislá soukromá práce, jíž se v kapitalistickém výrobním způsobu projevuje společenská dělba práce. Abstraktní práce je naturální látkou, materiální formou, která se realizuje sociálně zvláštním způsobem ve formě hodnoty. Hodnota je tedy „objektivizovanou sociální formou, jež mediuje organizaci čistě materiálního výdeje lidského těla“ v různých svých sociálních podobách (Starosta 2008: 312). Zatímco klasická politická ekonomie pojímala hodnotu jako čistě materiální formu, Rubin ji chápe jako formu čistě sociální (a tedy ne-materiální). Přehlížení materiální reality lidského světa mu znemožňuje vidět obecnou kontradikci, která existuje mezi abstraktní a konkrétní prací. Historicky specifickým výrazem tohoto univerzálního rozporu se pak dle Kicillofa a Starosty stává soukromá forma, jíž nabývá společenská práce v kapitalismu. Bezprostřední materiální proces lidského života takto produkuje určitý sociální vztah. „Neschopnost rozeznat a organizovat [...] sociální determinace lidské individuality“ pak dává v reálných historických podmínkách vyrůst kapitálu coby odcizenému společenskému subjektu; sociálnímu vztahu, v němž vládnou produkty předchozí práce svým tvůrcům (Kicillof a Starosta 2007a: 36). Překonání tohoto společenského vztahu se však nemůže odehrát jinak než na podkladě jeho kontradiktorního vývoje. Tento sociální proces však není pochopitelný ani realizovatelný, pokud z něj necitlivě vyjmeme materialitu abstraktní práce, která jej produkuje, což Rubin činí.

autonomistického marxismu De Angelisem. Ten chápe abstraktní práci jako antagonický třídní vztah. Podle De Angelise je vnucení odcizeného a bezbřehého charakteru abstraktní práce dělníkům aktivitou, která „abstrahuje“ od jejich ,žité zkušenosti“ (De Angelis 1995: 114). Rozdvojením jedné a té samé aktivity na abstraktní a konkrétní práci vzniká ve zbožní formě konfliktní opozice, která se transformuje v tř́́dní antagonismus mezi proletariátem jako stranou konkrétní práce a buržoazií jako stranou práce abstraktní (ibid.: 118). Zásadní vadou De Angelisova autonomistického pojetí je podle Kicillofa a Starosty (2007b: 15) to, že ve svém porozumění násilně činí z neprrimého sociálního vztahu, jímž je mediace hodnotovou formou, vztah přmí, politický vztah ovládání a moci. Pro De Angelise jde o vývoj dvou sociálních principů - na jedné straně uvalování abstraktní práce buržoazií, na druhé odpor dělnické třídy proti němu -, které jsou vůči sobě externí. Jelikož De Angelis nedokáže pochopit společnost jako vývoj odcizeného sociálního subjektu, sklouzává k ontologizaci tř́́dního boje. Kicillof a Starosta (ibid.: 28) se oproti tomu snaží o interní pochopení třídního boje a možnosti sociální transformace na podkladě kapitalistických sociálních forem, nebot' specifická podoba, kterou na sebe vezme všeobecná a vědomá organizace společenské práce, nebude ničím jiným než produktem konkrétního „momentu akumulace kapitálu“. 


\section{Bonefeldova kritika "fyziologického“ konceptu abstraktní práce}

Ani prŕístup Kicillofa se Starostou, kteří rozumí abstraktní práci jako spotřebování fyzické či mentální energie lidského těla za jistým produktivním účelem, nezůstal bez odezvy. Bonefeld, žák autorů Neue Marx-Lektüre a představitel proudu otevřeného marxismu, reagoval v časopise Capital \& Class kritikou jejich koncepce. Bonefeld (2010: 258) se zde staví proti chápání abstraktní práce coby „transhistorické kategorie, která je v kapitalismu ,reprezentována“ hodnotovou formou“. Oproti tomu důsledně brání a rozvíjí Rubinův přístup a abstraktní práci konceptualizuje jako „specifickou přechodnou formu kapitalistické práce“. Bonefeld ve své argumentaci vychází ze sociální konstituce kapitalistických sociálních forem. Užitné hodnoty uspokojují lidské potřeby, avšak tyto potřeby nejsou ve své výsledné podobě nijak historicky invariantní, jsou produktem živého člověka v jeho dějinné určenosti. „Hlad je hlad, ale hlad, který se tiší vařeným masem pojídaným vidličkou a nožem, je docela jiný hlad, než ten, který hltá syrové maso s pomocí rukou, nehtů a zubư“ (Marx 1971: 46). ${ }^{10}$ Co znamená tato historická proměnlivost lidských potřeb a práce, jejíž produkty tyto potřeby uspokojují, pro abstraktní práci? Především to, že odhlédneme-li od konkrétní práce, která vyrábí zboží, nenalezneme žádnou obecnou materialitu lidské práce, jak se domnívají Kicillof se Starostou, nýbrž jen př́rodní materii. Abstraktní práce pak nemůže existovat ve vztahu k práci konkrétní jako její biotický základ. Fyzická realita práce je vždy pouze konkrétní, nebot' „svaly nespalují cukr abstraktně“ (Bonefeld 2010: 266). A naopak, skutečnost, že se v jedné historicky přechodné společenské formaci různé produkty lidské práce stávají zbožím a jako takové mají jistou směnnou hodnotu, nelze vyvozovat z fyziologického základu práce, z prostého faktu tělesné existence člověka. „Přrirodní forma“ rozličných zboží ,je jejich konkrétní existence jako užitných hodnot“" (ibid.). Abstraktní práce je tedy pro Bonefelda výlučně společenská substance, která se stává viditelnou ve směně zboží, pro svou směnnou, a vưbec ne užitnou hodnotu. Podobně jako Rubin nebo Backhaus s Reicheltem proto Bonefeld chápe abstraktní práci jako reálnou abstrakci, jako ,,konstituovanou konceptualitu“ třídně rozdělené sociální praxe“ (Bonefeld 2004: 108).

Nová dimenze, kterou Bonefeld do uvažování o abstraktní práci a směně vnáší, se týká její specifické časovosti. Hodiny ukazují čas a měří pracovní dobu. Čas, který měří, se však neřídí vlastním rytmem vynakládané lidské aktivity; je tomu právě naopak: práce se zde objevuje zvěcnělá v homogenním čase. Tento čas se na lidskou činnost uvaluje jako externí objektivita; je to čas ,abstraktní a donucující“ (Bonefeld 2010: 267). Je to čas bez začátku a bez konce; nemá žádnou vlastní genezi ani historii; plyne odnikud nikam, „od tik k tak měří délku pracovní doby“. A přitom je to právě abstraktní čas, který si k sobě přivtěluje konkrétní lidskou práci. Děje se tak proto, že se čas konkrétní práce musí později ve směně validovat jako díl, jako moment společensky nutné pracovní doby; doby, která je ve společenském průměru a při průměrné intenzitě práce nutná pro výrobu daného zboží. Obtisk, který na pracovním procesu směna zanechává, lze nalézt právě v abstraktním charakteru časovosti, jež definuje hranice pracovního dne. Čas abstraktní práce je bezbřehý, nebot' reálná abstrakce,

10 Srov. Adorno (1990). 
kterou uvádí do pohybu ,P $-\mathrm{Z}-\mathrm{P}^{111}$, nemá jiný cíl než reprodukci sebe sama. Jestli se doba, po niž se vynakládala konkrétní práce, skutečně prokáže jako čas společensky nutné pracovní doby, se vyjevuje „post festum“ (Bonefeld 2010: 269). Nikdy totiž není předem známo, jestli bude konkrétní prací vyprodukované zboží s to obstát v tržní konkurenci jiných zboží stejného druhu.

Nikoli překvapivě proto Bonefeld dochází k závěru, že Kicillof se Starostou abstraktní práci fetišizují. Jejich vymezení abstraktní práce fyziologickou definicí zbavuje tento koncept kritického obsahu; maže distinkci mezi Marxem a politickou ekonomií, kterou Marx vztyčil právě na pochopení sociální specifičnosti kapitalistického výrobního způsobu, založeného na produkci zboží. Zboží vyrábí ve své materiální bezprostřednosti konkrétní práce, která se ve směnném procesu alikvotně prokazuje jako abstrakce společensky nutné pracovní doby. „Transhistorické zacházení s abstraktní prací převrací kritický vhled, že je dvojaký charakter práce specifický pro kapitalismus, vzhůru nohama. V transhistorické formulaci se abstraktní práce stává ontologickým základem všeho sociálního života“ (ibid.: 270). Naturalizace abstraktní práce má podle Bonefelda rovněž hořké politické konsekvence. Tato myšlenková procedura patří k pojetí společnosti, kde lidská práce existuje jako vykořistitelný zdroj, a ne jako svůj vlastní účel. Čas, který abstraktní práce na dělníky uvaluje, proti nim vystupuje jako moc, jež zcizuje jejich životy. I proto se hněv vzpoury obrací proti hodinám: ,přihodilo se, že se na několika místech Paříže, současně a navzájem nezávisle, stř́lelo do věžních hodin na kostelích“ (Benjamin 1979: 15). Komunismus, hnutí praktické negace reifikovaného světa reálně existujících kapitalistických abstrakcí, proto abstraktní práci ruší.

\section{Diskuze}

Bonefeldova polemická intervence do debaty o abstraktní práci vyvolala v časopise Capital \& Class další výměnu, do níž postupně zasáhli Carchedi (2011), znovu Kicillof se Starostou (2011) i Bonefeld (2011) a nakonec Holloway (2012). O plodný dialog mezi zastánci různých interpretací abstraktní práce však nešlo; diskuzi charakterizovalo spíše opevňování již obsazených pozic. Proto bude rozprava těchto př́spěvků jen velmi stručná. Carchedi (2011: 308309) ve svém třístránkovém př́spěvku reaguje na Bonefelda, črtá pochopení abstraktní práce jako ,zároveň fyziologické $i$ sociální kategorie s tř́dním obsahem“, cituje Marxe, aby došel k závěru, že abstraktní práce má „dvojaký charakter“. Kicillof a Starosta kritizují Bonefelda za neporozumění konceptuální determinaci kapitalistických sociálních forem a postavení tř́dního boje $\mathrm{v}$ jejich argumentaci. Jeho opovržení transhistorickou koncepcí abstraktní práce mírí mimo terč. Rekonstrukce abstraktní práce jako materiální reality lidského života, která se v kapitalismu objektivizuje ve formě hodnoty, implikuje, že mimo hodnotovou formu „neexistují žádné jiné historicky specifické sociální formy reprezentace [...] abstraktní práce“ (Kicillof a Starosta 2011: 298). Skutečnost, že kapitalistickou abstraktní práci charakterizuje hodnotová forma, neruší její všeobecně materiální povahu. Bonefeldův problém tkví v tom,

11 Všeobecný vzorec kapitálu popisuje nákup výrobních prostředků a pracovní síly za peníze, následnou výrobu zboží a extrakci nadhodnoty z pracovní síly a nakonec prodej výrobku za větší částku, než jaká se na začátku investovala, čímž dojde ke zhodnocení hodnoty (Marx 1978: kap. 4). 
že „přímo popírá realitu materiální identity mezi různými druhy užitečných konkrétních prací“ (ibid.: 300). Tuto identitu považuje za sociálně uvalovanou, což je evidentní lapsus. Marxova kritická teorie hodnoty je možná jen díky materiální skutečnosti kvalitativní stejnosti abstraktní práce, „(společensky nutná) pracovní doba determinuje množství hodnoty či ustavuje kvantitativni determinaci hodnoty. Ale abstraktní charakter (soukromě vykonávané) práce konstituuje substanci hodnoty, a tedy ustavuje její kvalitativni determinaci“ (ibid.: 301). $\mathrm{Na}$ Bonefeldovo pochopení vztahu abstraktní práce, třídního boje a komunismu pak Kicillof a Starosta vztahují podobnou kritiku jako na De Angelise (viz pozn. 9).

Ve svém druhém př́spěvku Bonefeld (2011: 407) namítá, že se Kicillof se Starostou staví proti těm koncepcím hodnoty, které ji považují za „smyslově nadsmyslnou“ realitu. ${ }^{12}$ Kapitalistická společnost pro ně není založena na panství určitých abstrakcí, nýbrž na „fyziologicky pojaté materialitě“. Jejich koncepce soukromé práce, která je pro ně specificky kapitalistickou prací, není s to pochopit společenský vztah, skrze nějž se v kapitalismu soukromá a nezávislá práce jako taková konstituuje. Volens nolens se proto ocitají na pozici politické ekonomie, nebot' důsledkem jejich teoretizace kapitalistické práce je teze, že soukromá práce produkuje hodnotu. A jak známo, mylný Ricardův názor, že individuálně vykonávaná práce př́mo vyrábí hodnotu, Marx konfrontoval poukazem na mediaci soukromé práce společensky nutnou pracovní dobou. Interpretace abstraktní práce, již Kicillof a Starosta razí, tedy neumožňuje kriticky (a vlastně ani marxisticky) proniknout kapitalistickou sociální realitu. Prozatímní tečku napsal za diskuzí abstraktní práce svým poetickým př́spěvkem Holloway (2012), myslitel Bonefeldovi velmi blízký. Ten se v duchu otevřeného marxismu staví za kritiku kapitalistických kategorií ad hominem. Zdůrazňuje, že konkrétní práce existuje „v-proti-a-za abstraktní prací“, že „existuje jako krize abstraktní práce“. Zatímco současná krize je jistým posunem, rekonfigurací konkrétní činnosti, „,revoluce je prolomením konkrétní aktivity proti-a-skrze abstraktní práci: kreativní síly lidské aktivity [...] proti-a-skrze dynamickou sociální kohezi, utkanou z abstraktní práce“.

$* * *$

Spíše než aby debatování abstraktní práce ustavilo konsenzus či alespoň mezi diskutujícími vytyčilo podstatný průsečík, došlo $\mathrm{k}$ uzavření rozpravy, která jasno do problému interpretace abstraktní práce věru nepřinesla. Všechno zlé je však pro něco dobré: spolu s tím, jak ve svých príspěvcích odhalovali různí autoři pozadí, podklad, na němž abstraktní práci u Marxe rozumí, vyjevovaly se čtenáři různé verze pochopení vědecké metody kritiky politické ekonomie. Od Rubinovy prvotní kritiky marxistické ortodoxie přes její novou recepci a rozvinutí v 70. letech až po její odmítnutí z „materialistické“ pozice Kicillofem se Starostou. Autor stati však považuje jejich chápání kritiky politické ekonomie, která se obráží i v jejich konceptualizaci abstraktní práce vis-à-vis ostatním kategorím kritiky politické ekonomie, za takovou verzi marxismu, která se nedostatečně rozchází s jeho mechanickou

12 Bonefeld má na mysli Marxovu (1978: 86) formulaci z první kapitoly Kapitálu, v níž Marx zachycuje ontologickou inverzi kapitalistické sociální praxe, která je produktem existence užitných hodnot jako zboží: ,jakmile vystupuje jako zboží, mění se ve smyslově nadsmyslnou věc““. 
formou. Jelikož diskuze vkladu Kicillofa a Starosty není účelem tohoto textu, omezí se jeho autor na několik tezí. Jejich rekonstrukce abstraktní práce sice je podložena citováním Marxových formulací, nicméně do značné míry ignoruje jejich hegelovskou expozici (na což správně upozorňují Rubin i Arthur), kdy pojem postupně přichází k sobě samému. Tato trnitá cesta se neobejde bez pokusů o projití slepých odboček a následných návratů zpět. Tyto nikam nevedoucí odchylky jsou však v průběhu rozvíjení argumentu též konceptuálně prozkoumávány. Proč tomu tak je? Jen dialektická expozice kategorií dokáže věrně zachytit kontradikci, vnitřní pnutí, agonický svár uvnitř sebe sama, který je kapitalistické konceptualitě vlastní. K tomuto procesu patří všechny momenty jeho vývoje, včetně těch, jež se později ukáží jako zcela marginální. Produktem dialektické metody expozice pak nejsou jen obsáhlé spisy, ale i zdánlivě si odporující výroky, formulace, jež však věrně obrážejí vývoj reálně existující kontradikce. ${ }^{13}$ Interpretace kategorií, jako je abstraktní práce, se pak může stávat problematickou a do jisté míry snad i nerozhodnutelnou, ale jistě by neměla připomínat „nazíravý materialismus, tj. materialismus, který chápe smyslovost ne jako praktickou činnost“, ale jako neměnnou, prrírodní skutečnost (Marx 1974: 8). Bonefeld oproti tomu zůstává věrný kritickému pojetí abstraktní práce ze známého dopisu, který poslal Marx (1957a: 151) Engelsovi 24. srpna 1867, tedy roku, kdy poprvé vyšel první díl Kapitálu: „To nejlepší na mé knize je [...] zdůrazněný dvojaký charakter práce podle toho, vyjadřuje-li se jako užitná nebo směnná hodnota (na tom spočívá veškeré pochopení faktů).“ Je tedy jasné, že autor stati jednoznačně preferuje „sociální“ či „sociologický“ koncept abstraktní práce před jeho čtením „materialistickým“ či „fyziologickým“.

\section{Závěr}

Tento text se snažil přispět ke zmírnění deficitu, který v české sociologii představuje velmi málo rozvinutá diskuze Marxova díla, zejména jeho sociologické metody. Využil k tomu sporu o abstraktní práci, jenž se udál $\mathrm{v}$ nedávné době a dotýká se konceptuálního zdroje partikulárních marxistických teorií, interní konceptuality kapitalistické společnosti. Marx mluví o dvojaké povaze práce, která produkuje zboží, přičemž konkrétní prací rozumí nějakou specifickou činnost. Abstraktní prací označuje práci v konkrétních aspektech bezrozdílnou; práci, jejíž vlastností je pouze to, že přidává svému výrobku hodnotu. Blíže vymezuje abstraktní práci na různých místech různými formulacemi, jež mohou zakládat jak její „materialistické“, tak i „sociologické“ pochopení. Abstraktní práci vždy exponuje ve vztahu k projektu a metodě kritiky politické ekonomie; otázkou zůstává, jakou roli tento koncept při zodpovězení fundamentálních otázek marxismu sehrává. Spor z poslední doby, na nějž tato stat' upřela svou pozornost, se týkal Rubinovy interpretace abstraktní práce, která prritáhla v posledních desetiletích zvýšenou pozornost zejména německých a britských autorů. Ti rozvíjejí Rubinovo pochopení ontologické inverze, kapitalisticky určitého převracení společenského subjektu, kreativní lidské činnosti, v objekt, v aktivitu člověka mediovanou hodnotovou formou. Rubin jim pomáhá uchopit problémy konstituce kapitalistické sociální reality.

13 Poučeně o vztahu Marxe a Hegela píše Simon Clarke (1991). 
On sám chápe abstraktní práci jako „sociální“ kategorii, jako výlučně kapitalistickou formu práce, přičemž Marxovy „fyziologické“ formulace interpretuje na pozadí rekonstrukce jeho metody.

Kicillof a Starosta Rubina kritizují pro jeho idealismus, pro přehnaný důraz na výrobní vztahy a zanedbávání zásadního významu vývoje výrobních sil. V jejich pojetí umožňuje koncept abstraktní práce zahrnout do kritiky politické ekonomie všeobecnou materialitu lidské produktivní činnosti, kvalitativně stejný charakter vydávání energie lidského těla. Za specificky kapitalistickou formu práce pak považují soukromou a nezávisle vykonávanou práci. Bonefeld hájí Rubina a s Kicillofem a Starostou polemizuje, nebot' jejich rekonstrukce abstraktní práce tenduje k afirmaci konstitutivní kapitalistické konceptuality, namísto aby marxisticky vyjadřovala kritiku fetišismu kapitalistických sociálních forem ad hominem. Debata mezi těmito autory ke sblížení jejich pozic sice nevedla, na druhou stranu se v publikovaných příspěvcích odhalily cenné indicie, které čtenáři umožňují zhodnocení diskutovaných koncepcí abstraktní práce ve vztahu k Marxově dialektické metodě. Různé přístupy k abstraktní práci byly ve vzájemných reakcích a kritikách interpretovány v širších marxistických souvislostech, byly zasazeny do různých pojetí vztahů mezi kategoriemi kritiky politické ekonomie. Autor se při hodnocení sporu postavil na stranu „rubinovců“. Stat' však usilovala především o zcitlivění čtenáře na komplexní charakter Marxovy argumentace a explikovala základní předpoklady, na jejichž základě je možno porozumět Marxově dialektické metodě a projektu kritiky politické ekonomie jako projektu kritiky vlastní konceptuality kapitalistické společnosti.

\section{Literatura}

ADORNO, Theodor W. Thesen über Bedürfnis. In ADORNO, Theodor W. Gesammelte Schriften, Band 8. Frankfurt am Main: Suhrkamp Verlag, 1990, s. 392-396. ISBN 3-518-57226-1.

ADORNO, Theodor W. (ed.). Der Positivismusstreit in der deutschen Soziologie. München: Deutscher Taschenbuch Verlag, 1993. ISBN 3423046201.

ARTHUR, Christopher J. Value, Labour and Negativity. Capital \& Class, 2001, roč. 25, č. 1, s. 15-39. ISSN 0309-8168.

ARTHUR, Christopher J. The Inner Totality of Capitalism. Historical Materialism, 2006, roč. 14, č. 3, s. 85-111. ISSN 1465-4466.

BACKHAUS, Hans-Georg. On the Dialectics of the Value-Form. Thesis Eleven, 1980, roč. 1, č. 1, s. 99-120. ISSN 0725-5136.

BACKHAUS, Hans-Georg. Between Philosophy and Science: Marxian Social Economy as Critical Theory. In BONEFELD, Werner, Richard GUNN a Kosmas PSYCHOPEDIS (eds.). Open Marxism, Vol. I: Dialectics and History. London: Pluto Press, 1992, s. 54-92. ISBN 0745305903.

BACKHAUS, Hans-Georg. Some Aspects of Marx's Concept of Critique in the Context of his Economic-Philosophical Theory. In BONEFELD, Werner a Kosmas PSYCHOPEDIS (eds.). Human Dignity: Social Autonomy and the Critique of Capitalism. Aldershot: Ashgate, 2005, s. 13-29. ISBN 0754644685.

BACKHAUS, Hans-Georg. Dialektik der Wertform: Untersuchungen zur Marxschen Ökonomiekritik. Freiburg: Caira, 2011. ISBN 3-924627-52-5. 
BENJAMIN, Walter. Dějinně filozofické teze. In BENJAMIN, Walter. Dílo a jeho zdroj. Praha: Odeon, 1979, s. 9-16.

BONEFELD, Werner. On Postone's Courageous but Unsuccessful Attempt to Banish Class Antagonism from the Critique of Political Economy. Historical Materialism, 2004, roč. 12, č. 3, s. 103-124. ISSN 1465-4466.

BONEFELD, Werner. Abstract Labour: Against Its Nature and on Its Time. Capital \& Class, 2010, roč. 34, č. 2, s. 257-276. ISSN 0309-8168.

BONEFELD, Werner. Debating Abstract Labour. Capital \& Class, 2011, roč. 35, č. 3, s. 475-479. ISSN 1465-4466.

BONEFELD, Werner. Negative Dialectics in Miserable Times: Notes on Adorno and Social Praxis. Journal of Classical Sociology, 2012, roč. 12, č. 1, s. 122-134. ISSN 1468-795X.

BONEFELD, Werner, Richard GUNN a Kosmas PSYCHOPEDIS (eds.). Open Marxism, Vol. I: Dialectics and History. London: Pluto Press, 1992a. ISBN 0745305903.

BONEFELD, Werner, Richard GUNN a Kosmas PSYCHOPEDIS (eds.). Open Marxism, Vol. II: Theory and Practice. London: Pluto Press, 1992b. ISBN 0745305911.

BONEFELD, Werner, Richard GUNN, Kosmas PSYCHOPEDIS a John HOLLOWAY (eds.). Open Marxism, Vol. III: Emancipating Marx. London: Pluto Press, 1995. ISBN 0745308635.

CARCHEDI, Guglielmo. A Comment on Bonefeld's 'Abstract Labour: Against Its Nature and on Its Time.' Capital \& Class, 2011, roč. 35, č. 2, s. 307-309. ISSN 0309-8168.

CLARKE, Simon. Marx, Marginalism and Modern Sociology: From Adam Smith to Max Weber. London: Palgrave Macmillan, 1991. ISBN 978-0-333-54829-5.

DE ANGELIS, Massimo. Beyond the Technological and the Social Paradigms: A Political Reading of Abstract Labour as the Substance of Value. Capital \& Class, 1995, roč. 19, č. 3, s. 107-134. ISSN 0309-8168.

HOLlOWAY, John. Crisis and Critique. Capital \& Class, 2012, roč. 36, č. 3, s. 515-519. ISSN 0309-8168.

HOLLOWAY, John a Sol PICCIOTTO (eds.). State and Capital: A Marxist Debate. London: Edward Arnold, 1978. ISBN 0-7131-5987-1.

HOLLOWAY, John, Fernando MATAMOROS a Sergio TISCHLER (eds.). Negativity and Revolution: Adorno and Political Activism. London: Pluto Press, 2009. ISBN 9780745328362.

HOLMWOOD, John. Z roku 1968 do roku 1951: Jak Habermas proměnil Marxe v Parsonse. Sociologický časopis, 2008, roč. 44, č. 5, s. 923-942. ISSN 0038-0288.

KICILLOF, Axel a Guido STAROSTA. On Materiality and Social Form: A Political Critique of Rubin's Value-Form Theory. Historical Materialism, 2007a, roč. 15, č. 3, s. 9-43. ISSN 1465-4466.

KICILLOF, Axel a Guido STAROSTA. Value Form and Class Struggle: A Critique of the Autonomist Theory of Value. Capital \& Class, 2007b, roč. 31, č. 2, s. 13-40. ISSN 1465-4466.

KICILLOF, Axel a Guido STAROSTA. On Value and Abstract Labour: A Reply to Werner Bonefeld. Capital \& Class, 2011, roč. 35, č. 2, s. 295-305. ISSN 1465-4466.

KLIMAN, Andrew. The Failure of Capitalist Production. London: Pluto Press, 2012. ISBN 0745332390.

LOEWENSTEIN, Bedřich. Marx v Masarykově prizmatu. Sociologický časopis, 1998, roč. 34, č. 4, s. 403-415. ISSN 0038-0288.

MARADA, Radim. Občanská společnost: mezi inkluzí a exkluzí. Sociální studia, 2005, roč. 2, č. 1, s. 7-11. ISSN 1214-813X.

MARX, Karel. Mzda, cena a zisk. Praha: Svoboda, 1949.

MARX, Karel. Kapitál: Kritika politické ekonomie. Díl druhý, kniha druhá. Praha: SNPL, 1955a.

MARX, Karel. Ke kritice politické ekonomie. Praha: SNPL, 1955b.

MARX, Karel. Marx Engelsovi, 24. srpna 1867. In MARX, Karel a Bedřich ENGELS. Dopisy $o$, Kapitálu“. Praha: SNPL, 1957a, s. 148-152. 
MARX, Karel. Marx Kugelmannovi, 30. listopadu 1867. In MARX, Karel a Bedřich ENGELS. Dopisy o „Kapitálu“. Praha: SNPL, 1957b, s. 161.

MARX, Karel. Ekonomicko-filosofické rukopisy z roku 1844. Praha: SNPL, 1961.

MARX, Karel. Rukopisy „, Grundrisse“ I. Praha: Svoboda, 1971.

MARX, Karel. Teze o Feuerbachovi. In MARX, Karel a Friedrich ENGELS. O historickém materialismu. Praha: Svoboda, 1974, s. 5-8.

MARX, Karel. K židovské otázce. In MARX, Karel a Bedřich ENGELS. O židovské otázce. Praha: Svoboda, 1975, s. 5-40.

MARX, Karel. Kapitál: Kritika politické ekonomie. Díl prvni. Praha: Svoboda, 1978.

NEDBÁLKOVÁ, Kateřina. Tak daleko a tak blízko: Dělnická třída v České republice. Sociální studia, 2012, roč. 9, č. 3, s. 85-100. ISSN 1214-813X.

NOVÝ, Martin. Realita konceptu a iluze reality: Ke kritickému založení Adornovy sociologie. (Rukopis). 2014.

PETRUSEK, Miloslav. Návrat (sociologické) teorie do Čech? Východiska, stav a perspektivy. Sociologický časopis, 2011, roč. 47, č. 5, s. 1017-1033. ISSN 0038-0288.

REICHELT, Helmut. Why Did Marx Conceal His Dialectical Method? In BONEFELD, Werner, Richard GUNN, Kosmas PSYCHOPEDIS a John HOLLOWAY (eds.). Open Marxism, Vol. III: Emancipating Marx. London: Pluto Press, 1995, s. 40-83. ISBN 0745308635.

REICHELT, Helmut. Habermas' Reconstruction of Historical Materialism. In BONEFELD, Werner a Kosmas PSYCHOPEDIS (eds.). The Politics of Change: Globalization, Ideology and Critique. Basingstoke: Palgrave, 2000, s. 105-145. ISBN 0312235593.

REICHELT, Helmut. Social Reality as Appearance: Some Notes on Marx's Conception of Reality. In BONEFELD, Werner a Kosmas PSYCHOPEDIS (eds.). Human Dignity: Social Autonomy and the Critique of Capitalism. Aldershot: Ashgate, 2005, s. 31-67. ISBN 0754644685.

REICHELT, Helmut. Marx's Critique of Economic Categories: Reflections on the Problem of Validity in the Dialectical Method of Presentation in Capital. Historical Materialism, 2007, roč. 15, č. 4, s. 3-52. ISSN 1465-4466.

RUBIN, Isaac I. Abstract Labour and Value in Marx‘s System. Capital \& Class, 1978, roč. 2, č. 2, s. 107-139. ISSN 1465-4466.

RUBIN, Isaac I. Essays on Marx's Theory of Value. New York: Black Rose Books, 1990. ISBN 0-919618-9.

STAROSTA, Guido. The Commodity-Form and the Dialectical Method: On the Structure of Marx's Exposition in Chapter 1 of Capital. Science \& Society, 2008, roč. 72, č. 3, s. 295-318. ISSN 1836-6236.

\section{Autor}

Martin Nový je doktorandem na Fakultě sociálních studií Masarykovy univerzity v Brně. Mezi okruhy jeho odborného zájmu patři marxistická a kritická sociální teorie. V současné době pracuje na své dizertaci, jejímž tématem je Adornova sociologická metoda.

Kontakt:216683@mail.muni.cz 